\title{
Article \\ Effects of Urbanization on Landscape Patterns in the Middle Reaches of the Yangtze River Region
}

\author{
Yang Yi ${ }^{1,2,3,4}{ }^{\oplus}$, Chen Zhang ${ }^{4}$, Guilian Zhang ${ }^{1}$, Luqi Xing ${ }^{1}$, Qicheng Zhong ${ }^{1}$, Jialin Liu ${ }^{1,5}$, Yichen Lin ${ }^{1}$, \\ Xiewei Zheng ${ }^{1}$, Na Yang ${ }^{1}$, Hao Sun ${ }^{4}$, Mingchang Shi ${ }^{3}$ and Hongzhang Kang ${ }^{2,6, *(\mathbb{B}}$
}

1 Key Laboratory of National Forestry and Grassland Administration on Ecological Landscaping of Challenging Urban Sites, National Innovation Alliance of National Forestry and Grassland Administration on Afforestation and Landscaping of Challenging Urban Sites, Shanghai Engineering Research Center of Landscaping on Challenging Urban Sites, Shanghai Academy of Landscape Architecture Science and Planning, Shanghai 200232, China; yy@shsyky.com (Y.Y.); zgl@shsyky.com (G.Z.); xlq@shsyky.com (L.X.); zqc@shsyky.com (Q.Z.); jialinliu@seas.harvard.edu (J.L.); lyc@shsyky.com (Y.L.); zxw@shsyky.com (X.Z.); yn@shsyky.com (N.Y.)

2 School of Agriculture and Biology, Shanghai Jiao Tong University, Shanghai 200240, China

3 Beijing Engineering Research Center of Soil and Water Conservation, Beijing Forestry University, Beijing 100083, China; shimc@bjfu.edu.cn

4 Shanghai Foundation Ding Environmental Technology Company, Shanghai 200063, China; joezhangchen@sina.com (C.Z.); sunhao930309@163.com (H.S.)

5 Harvard China Project, Harvard John A. Paulson School of Engineering and Applied Sciences, Cambridge, MA 02138, USA

6 School of Design, Shanghai Jiao Tong University, Shanghai 200240, China

Citation: Yi, Y.; Zhang, C.; Zhang, G.; Xing, L.; Zhong, Q.; Liu, J.; Lin, Y.; Zheng, X.; Yang, N.; Sun, H.; et al. Effects of Urbanization on Landscape Patterns in the Middle Reaches of the Yangtze River Region. Land 2021, 10, 1025. https://doi.org/10.3390/ land10101025

Academic Editors: Luca Salvati and Diane Pearson

Received: 27 July 2021

Accepted: 17 September 2021

Published: 30 September 2021

Publisher's Note: MDPI stays neutral with regard to jurisdictional claims in published maps and institutional affiliations.

Copyright: () 2021 by the authors. Licensee MDPI, Basel, Switzerland. This article is an open access article distributed under the terms and conditions of the Creative Commons Attribution (CC BY) license (https:// creativecommons.org/licenses/by/ $4.0 /)$.
Abstract: The middle reaches of the Yangtze River region (MRYRR) are China's first trans-regional urban agglomeration, located in the center of the Yangtze River Economic Belt. The MRYRR is an important ecological reserve, and its land cover changes are affected by both socio-economic development and geographical environment. In this paper, Landsat ETM/TM/OLI remote sensing images were used to monitor land use and landscape patterns from 1990 to 2015. Through supervised classification, land use transfer matrix, landscape pattern metrics and correlation analysis, the spatialtemporal patterns of land use change and its relationship with socio-economic in the study area were revealed. The results showed that: (1) the main land use types in the study area were cropland (CL) and forestland (FL), accounting for more than three-quarters of the study area. During the study period, built-up land (BL) increased, CL decreased, FL increased first and then decreased; (2) the BL expanded mainly by occupying CL and FL, and regional landscape pattern was gradually fragmented, with complex patch shape and increasing diversity and heterogeneity. Among them, the BL is gradually gathered, and the FL and CL are gradually fragmented; (3) in the past 25 years, the urbanization process in this region has been obvious, and the Gross Domestic Product (GDP) has increased by 36 times. The socioeconomic variables were positively correlated with BL, orchard (OL) and Shannon diversity index (SHID), and negatively correlated with CL, Wasteland (WL), mean patch size (MPS) and contagion size (CONTAG). The results showed that the urbanization development has a great impact on the region, and the ecological protection task is still challenging. It is necessary to protect high-quality cropland and draw a red line for ecological protection. We should strengthen the construction of ecological corridors and ecological nodes to adapt to regional sustainable development.

Keywords: urbanization; land use transition; landscape patterns; middle reaches of the Yangtze River region; correlation analysis 


\section{Introduction}

Since the 20th century, with the rapid development of economy and the rapid increase of urban population, the intensification of human activities such as urbanization and industrialization have had a serious impact on regional land use, vegetation cover and ecological environment [1-3]. Therefore, a series of ecological problems have emerged, such as climate warming, water pollution, low forest efficiency, soil erosion, etc., [4,5]. Deforestation, urban construction and over exploitation of tourism resources destroy the natural growth of regional vegetation, resulting in soil erosion, low vegetation coverage, fragmentation of vegetation patches and other problems, which have a significant impact on the overall regional ecological environment balance of the region, and endanger the integrity and sustainability of the ecosystem [6,7]. As the world population continues to increase, the global urbanization process will accelerate, especially in developing countries [8]. With destruction of the ecological environment and the decline of forest coverage, China's urbanization rate increased from $17.90 \%$ in 1978 to $60.60 \%$ in 2019 [9-11]. Forest cover in MRYRR is decreasing, which exacerbates the phenomenon of soil erosion [12,13]. Therefore, the Sediment content of the Yangtze River Basin is relatively high, ranking the fourth in the world with a value of $1.18 \mathrm{~kg} \cdot \mathrm{m}^{-3}$, and washing away as much as 900 million tons of sediment every year [14]. However, there are relatively few studies on land use change and its driving factors in MRYRR. Therefore, it is of great significance to study the change of regional land use and landscape pattern and its driving factors.

Spatial and temporal patterns of land use types and landscape patterns were the important topics in global change and land science $[15,16]$. The Land Use/Cover Change (LUCC) scientific research program was jointly developed and published by the International Geosphere Biosphere Program (IGBP) and the International Human Dimensions Program on Global Environmental Change (IHDP) in 1995 [17]. Spatial and temporal pattern analysis of regional land use change was the most basic content and the earliest research field of this research program $[18,19]$. Landscape pattern analysis method was defined as patch type, quantity and spatial distribution in landscape structure [20]. Analysis and research on land use and landscape patterns analysis gradually shifted from simple and intuitive qualitative research to quantitative analysis combined with spatial distribution [21]. The main representatives of land use and landscape patterns researches are Forman [22], Pickett [23], Turner [24], Risser [25], Wang [26], Wu [27], etc. With the development of RS and GIS technology, since the 21st century, Alejandro [28], Ellis [29], Munroe [30], Fu [31], Louisa [32] and other representative studies have laid a good foundation for land use and landscape pattern research.

In recent years, scholars have done a lot of research on the landscape patterns. Methods mainly focus on land use transfer matrix, dynamic change mathematical model, landscape measurement, gradient analysis, etc. [33-35]. Its achievements mainly focused on landscape patterns change [36], urbanization process and ecological eco-environment effects [37], driving mechanism [38], and land use model simulation and prediction [39]. Based on the vegetation map, Ma et al. chose a variety of landscape metrics to analyze and evaluate the landscape fragmentation in Dongling Mountain [40]. Zhang et al. established ecological risk index based on remote sensing data and analyze the temporal and spatial characteristics of ecological risk in Shiyang River Basin by using landscape indicators, which is of great significance to optimizing the land use structure and landscape pattern of the basin and maintaining the ecological function of the basin [41]. Qi et al. analyzed the landscape patterns of small and medium-sized cities in the Yangtze River Delta and Xinjiang and discussed the differences and driving factors of land use and landscape pattern change among regions based on population and economic data [42]. Fan et al. [43], Kim et al. [44], Huang et al. [45] and Asimeh et al. [46] analyzed and discussed the changes of land use and landscape patterns in different regions, obtaining important enlightenment, which providing important theoretical basis for regional land use planning and landscape optimization. However, studies on land use and landscape patterns changes in China were mainly concentrated in cities $[47,48]$, and study areas were mainly concentrated in the 
eastern coastal area [49]. The quantitative analysis of land use change and socio-economic driving forces of typical urban agglomerations in MRYRR is relatively rare.

Urban agglomeration in the MRYRR was the first approved national urban agglomeration in China [50]. MRYRR was the second largest urban agglomeration in China after the Yangtze River Delta urban agglomeration [51]. In April 2015, the development plan of MRYRR urban agglomeration was released, indicating that MRYRR urban agglomeration has become a key area for the implementation of ecological priority green development strategy in the Yangtze River economic belt [52,53]. Under the national strategy of coordinated regional development and the strategy of the rise of central China, the Yangtze River Delta urban agglomeration, as an important part of the Yangtze River Economic Belt, played a key role and was the core hub connecting the central and western regions with the Yangtze River Delta and the Hong Kong-Macao Bay area in Guangdong [54]. The MRYRR includes Hubei Province, Hunan Province and Jiangxi Province. Due to its unique mountainous terrain, geographical environment and climate characteristics, this area was rich in natural vegetation resources and was an important ecological protection area in China [50]. This area connected the upper and lower reaches of the Yangtze River and had obvious transition characteristics. Regional natural ecological development was of great significance for maintaining the ecological sustainable development of the whole Yangtze River basin $[55,56]$. The urbanization process in this area was typical and representative. It was of great significance to study the spatio-temporal changes of land use and landscape patterns and their coupling coordination with social, economic and ecological environmental systems.

Based on the remote sensing data and socio-economic data from 2000 to 2015, this study selected the MRYRR (Hubei Province, Hunan Province and Jiangxi Province) to analyze the change characteristics and evolution trend of land use and landscape patterns and determine the driving factors of land use and landscape pattern in this region. The purposes were to: (1) reveal the spatial-temporal dynamic characteristics of land use in the MRYRR; (2) evoke the trend of landscape patterns in the MRYRR; (3) analyze the relationship between social, economic and population factors and land use, and landscape pattern change. This study could provide scientific reference for regional urbanization sustainable development and ecological environment construction measures.

\section{Study Area}

The MRYRR includes Hubei Province, Hunan Province and Jiangxi Province $\left(24^{\circ} 25^{\prime}\right.$ $\mathrm{N}-33^{\circ} 16^{\prime} \mathrm{N}, 108^{\circ} 24^{\prime} \mathrm{E}-118^{\circ} 23^{\prime} \mathrm{E}$ ), with a total area of $564,000 \mathrm{~km}^{2}$ (Figure 1). The regional climate type is subtropical monsoon climate, with precipitation of $1000-1600 \mathrm{~mm} \cdot \mathrm{a}^{-1}$ and annual average temperature of $16-18{ }^{\circ} \mathrm{C}$ [57]. The MRYRR mainly consists of mountainous hills and plains, which account for $48.3 \%$ and $14.8 \%$ of the area, respectively. The area has an average altitude of about $1500 \mathrm{~m}$ [36]. MRYRR has three agglomeration areas, including Wuhan Metropolitan Area, Poyang Lake Metropolitan area and ChangshaZhuzhou-Tan Metropolitan area, making MRYRR one of the most important national urban agglomerations in China [58]. In 2018, the total population of this region was 174.38 million, accounting for $12.7 \%$ of the total population of China, with a GDP of 9.8 trillion yuan. The urbanization level exceeded $50 \%$, with frequent human economic activities and large regional disturbances [59]. 




Figure 1. Locations of the MRYRR.

\section{Materials and Methods}

\subsection{Data Sources and Processiong}

The data form Landsat TM/ETM/OLI remote sensing images (https:/ /www.usgs. gov/, accessed on 14 August 2021) in 1990, 2000, 2010 and 2015 were used in this study [60]. Combined with the 2017 China land cover classification standard system and the land use characteristics of land use types in the study area, supervision and classification were carried out. Land use types were divided into eight types: cropland (CL), forestland (FL), shrubland (SL), orchard (OL), grassland (GL), waterbodies (WB), built-up land (BL) and wasteland (WL) (Table 1). One hundred and sixty samples were randomly selected, and high-resolution images were used to detect Google Earth $\left(10 \times 10 \mathrm{~m}^{2}\right)$ and interpret the accuracy. The overall accuracy was above $74 \%$ and kappa coefficient was above 0.70 . All operations were performed using the ENVI 5.3 software. Socioeconomic factors (population, urban residents, rural residents, GDP, per capita GDP, primary sector, secondary sector, tertiary sector) are derived from the statistical yearbook [61-64].

Table 1. Land use types in the study area (based on the Chinese National Standard and Yi) $[65,66]$.

\begin{tabular}{cc}
\hline Land Cover Types & Description \\
\hline Grassland (GL) & $\begin{array}{c}\text { Refers to growing herbaceous plants, including pasture or mainly pasture. } \\
\text { Refers to land for planting crops, including cultivated land, new open } \\
\text { wasteland, wheeled land, and crop fields so as to cultivate rice, lotus root, } \\
\text { and other aquatic crops. }\end{array}$ \\
$\begin{array}{c}\text { Forestland (FL) } \\
\text { Shrubland (SL) }\end{array}$ & $\begin{array}{r}\text { It mainly refers to natural forests and plantations } \\
\text { Short woodlands and shrubs. }\end{array}$ \\
Orchard (OL) & $\begin{array}{r}\text { Refers to many years of intensive planting of woody and herbaceous crops } \\
\text { for the intensive management of fruit, leaves, roots, stems, and juices. } \\
\text { All types of manmade structures: Residential, industrial, agricultural } \\
\text { commercial and services; transportation and utilities. }\end{array}$ \\
Wuilt-up land (BL) & $\begin{array}{r}\text { Refers to natural land waters and land for water conservancy facilities, } \\
\text { including reservoirs, ponds, rivers, lakes, snow, oceans and submerged } \\
\text { land, etc. }\end{array}$ \\
Wasteland (WL) & The surface is rock or gravel, bare soils, sand, and bare stone. \\
\hline
\end{tabular}

\subsection{Study Methods}

\subsubsection{Land Use Transfer Matrix}

Land use transfer matrix is a two-dimensional matrix based on the relationship between land cover change in two different periods in the same region. By analyzing the transformation matrix, we can get the conversion between two different periods of different land categories. It can not only reflect the area of various land types at a static time point, but also reflect the output information of land cover in the early stage and the 
income information in the later stage. Land use transfer matrix can visually describe the spatio-temporal change process of land use [67].

$$
S_{i j}=\left[\begin{array}{ccccc}
S_{11} & S_{12} & S_{13} & \cdots & S_{1 n} \\
S_{21} & S_{22} & S_{23} & \cdots & S_{2 n} \\
S_{31} & S_{32} & S_{33} & \cdots & S_{3 n} \\
\vdots & \vdots & \vdots & \vdots & \vdots \\
S_{n 1} & S_{n 2} & S_{n 3} & \cdots & S_{n n}
\end{array}\right]
$$

where $S_{i j}$ is the area of class $i$ land converted into class $j$ (The $i=j$ represents the unchanged area of a certain land use type); $i$ and $j$ respectively represent the land use types before and after the transfer. $n$ is the number of land use types ( $n=8$ in this paper).

In order to clearly express the data of land use transfer from 1990 to 2015, we made a graph called circos and listed the data as Appendix A (Figure 2 and Tables 3-6). Graphing method used the template (http:/ / mkweb.bcgsc.ca/tableviewer/ accessed on 14 August 2021) by Canada's Michael Smith Genome Sciences Centre (CMSGSC) [68]. The illustration is as follows:

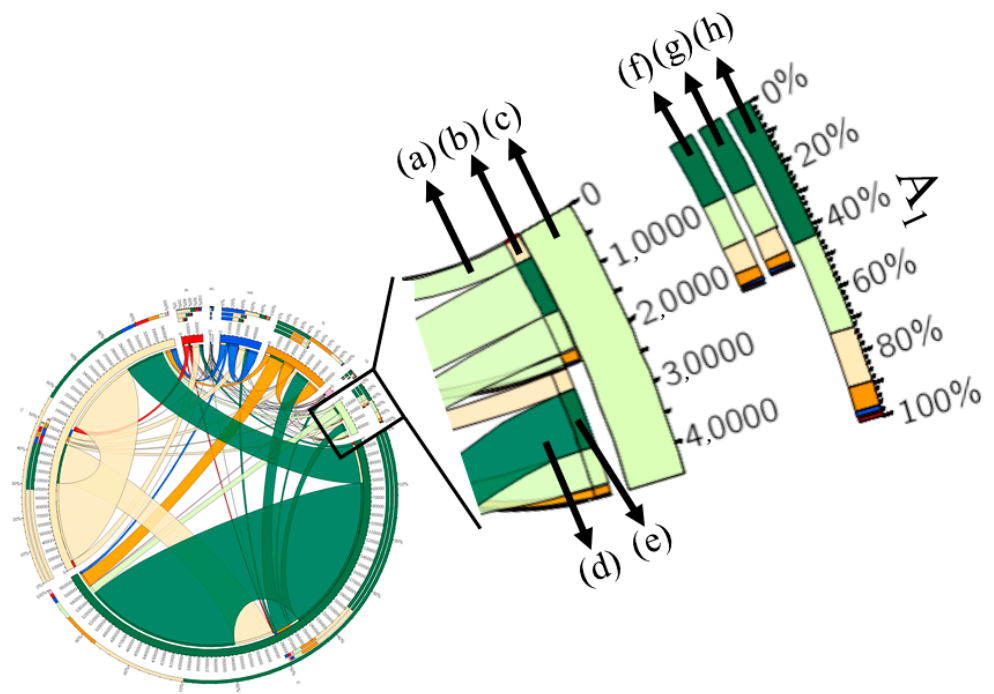

Figure 2. An explanation of the circos chart. Each stripe represents the occurrence of a transformation process at two different times, and the color represents the land use types. (a) The area of $\mathrm{A}_{1}$ transformed into other land use types; (b) The types of land use transformed from $\mathrm{A}_{1}$; (c) The total area of $A_{1}$ transformed out and transformed into; (d) The area of $A_{1}$ transformed from other land use types; (e) The types of land use transformed into $A_{1}$; (f) The proportion of each land use types in transferred from $\mathrm{A}_{1} ;(\mathrm{g})$ The proportion of each land use types in transferred into $\mathrm{A}_{1} ;(\mathbf{h})$ The total amount of $A_{1}$ transferred into and transferred out.

\subsubsection{Quantification of Landscape Patterns}

Landscape metrics are widely used to quantitatively describe the changes of regional landscape patterns $[69,70]$. According to the diversity of land use types in the study area, relevant metrics were selected, mainly including landscape metrics that could reflect area, density, diversity, connectivity and shape (Table 2). Fragstats 3.3 software is used to calculate the landscape metrics.

\subsubsection{Statistical Analysis}

Statistical correlations among land use types (CL, FL, SL, OL, GL, WB, BL and WL), landscape patterns (PD, LPI, MPS, NP, SHDI, and CONTAG) and urbanization metrics (POP, RUR, URR, GDP, PGDP, PRI, SEC, TER) were calculated. $p$ value less than 0.05 was considered a significant correlation [71]. All statistical analyses were performed using SPSS 20 software. 
Table 2. Description of landscape metrics.

\begin{tabular}{|c|c|c|c|}
\hline Structural Category & Landscape Metrics & Abbreviation & Description \\
\hline \multirow{4}{*}{ Area/Density } & Patch density & PD & \multirow{4}{*}{$\begin{array}{c}\text { Number of patches per unit area in a landscape } \\
\text { Area of the largest patch } \\
\text { The average mean surface of patches } \\
\text { The total number of patches can reflect the spatial } \\
\text { pattern of landscape }\end{array}$} \\
\hline & Largest Patch Index & LPI & \\
\hline & Mean Patch Area & MPS & \\
\hline & Number patches & $\mathrm{NP}$ & \\
\hline Diversity & Shannon diversity index & SHDI & Detection of Landscape Diversity \\
\hline \multirow[t]{2}{*}{ Connectivity } & Patch Cohesion Index & COHESION & $\begin{array}{l}\text { Increases as the patches of the corresponding } \\
\text { patch type become less connected }\end{array}$ \\
\hline & Contagion index & CONTAG & $\begin{array}{l}\text { The degree of aggregation and extension of certain } \\
\text { patches within a landscape }\end{array}$ \\
\hline Shape & Landscape shape index & LSI & Represents the complexity of the boundary shape \\
\hline
\end{tabular}

\section{Results}

4.1. Land Use Change in the MRYRR from 1990 to 2015

4.1.1. Characteristics of Spatiotemporal Change of Land Use

From 1990 to 2015, the MRYRR experienced significant land use transfer changes. FL and CL were the main land use types in the study area, and the land use area in the order from large to small was always as follows: FL > CL > SL > WB > GL > BL > OL > WL (Figure 3). In 1990 and 2015, the proportion of CL was $31.47 \%$ and $30.41 \%$, and that proportion of FL was $50.31 \%$ and $49.82 \%$, respectively, the sum of which reached about $80 \%$ (Table 2, Figures 3 and 4). BL accounted for about $1.73 \%$ to $2.81 \%$ of the whole study area, showing an overall growth trend. The area of BL increased by $7.67 \%, 17.36 \%$ and $28.61 \%$, respectively. CL and SL decreased, while FL and WL fluctuated greatly. OL showed a decreasing trend before 2000 and gradually increased after 2000.

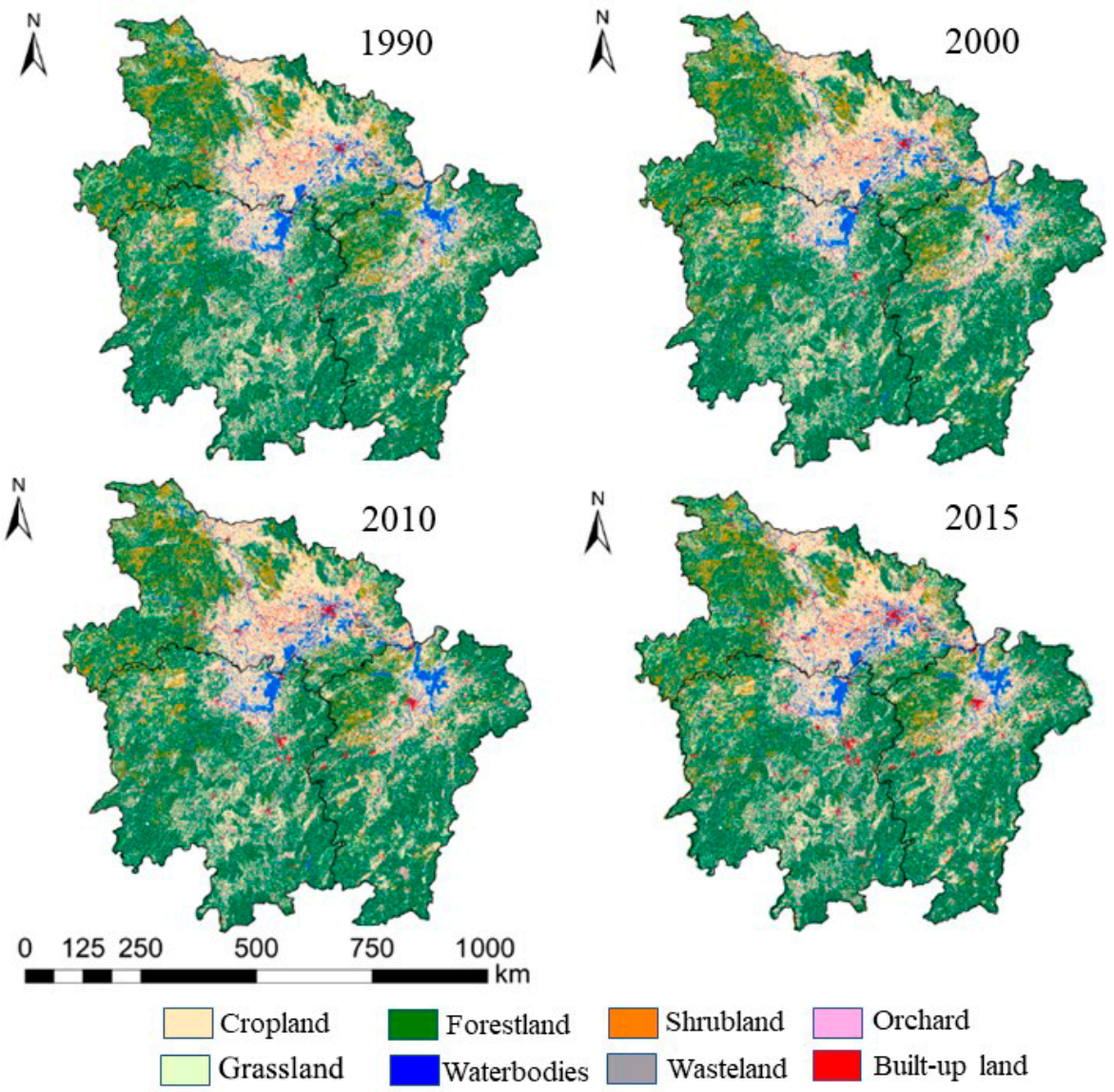

Figure 3. Spatiotemporal change of land use types in the MRYRR from 1990 to 2015. 


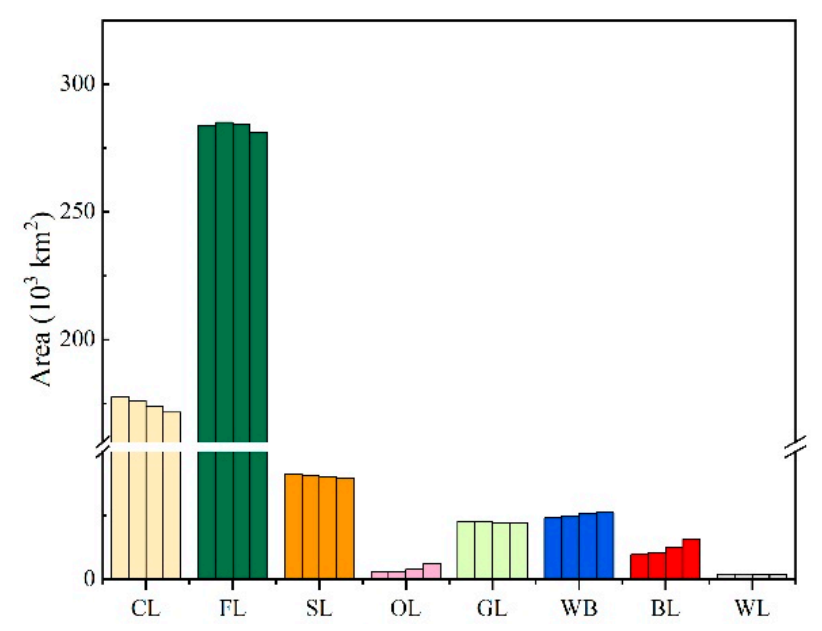

Figure 4. Changes in land use types in the MRYRR region from 1990 to 2015 . The data in the color histogram represent the area of land use types in the study period (1990, 2000, 2010 and 2015) from left to right. Details of the abbreviations are shown in Table 2.

\subsubsection{Characteristics of Land Use Transfer Changes}

From 1990 to 2000, the area of BL in the MRYRR increased by $749 \mathrm{~km}^{2}$, an increase of $7.67 \%$. In the past 10 years, the total area of CL decreased by $1524 \mathrm{~km}^{2}(0.86 \%)$. The total area of FL increased by $1179 \mathrm{~km}^{2}$, mainly from CL and SL. From 1990 to 2000, the intensity of land use type transfer within the study area was relatively high (Figure 5a). From 2000 to 2010 , BL increased by $1825 \mathrm{~km}^{2}$, an increase of $17.36 \%$. Among them, $1221 \mathrm{~km}^{2}$ and $474 \mathrm{~km}^{2}$ came from CL and FL. The OL area increased by $1048 \mathrm{~km}^{2}$, most of which came from FL. The area of CL decreased by $2042 \mathrm{~km}^{2}$, most of which was converted into FL, OL and WB. From 2000 to 2010, the intensity of transfer between land use types in this region was low, with the transfer proportion less than $20 \%$. Among them, CL has the highest transfer intensity (Figure 5b).

From 2010 to 2015, BL increased by $3529 \mathrm{~km}^{2}$, an increase of $28.61 \%$. Among them, the areas from CL and FL were $2123 \mathrm{~km}^{2}$ and $1127 \mathrm{~km}^{2}$ respectively. The changes of OL area mainly came from FL, with an increase of $2120 \mathrm{~km}^{2}$. The area of CL was decreased by $2450 \mathrm{~km}^{2}$, which was mainly transferred to BL. During this period, the intensity of transfer in the MRYRR was small, with the proportion of transfer less than $1.6 \%$. In terms of land use transfer out, CL has the largest transfer out intensity, and the transfer out area accounts for 1.6\% (Figure 5c). In the 25 years from 1990 to 2015, BL increased by $6103 \mathrm{~km}^{2}$, an increase of $62.52 \%$, with an average annual increase of $244.12 \mathrm{~km}^{2}$. Various land use types have been transferred to $\mathrm{BL}$, and $\mathrm{CL}$ and $\mathrm{FL}$ were the main land use types converted to BL. The area of FL decreased by $2808 \mathrm{~km}^{2}$, and FL transferred to CL (17.41\%), SL (6.56\%) and others $(0.85 \%)$. The area of CL decreased by $6016 \mathrm{~km}^{2}$, with an annual decrease of $240.64 \mathrm{~km}^{2}(20 \%)$. OL increased by $3005 \mathrm{~km}^{2}$, WL decreased by $273 \mathrm{~km}^{2}$, GL decreased by $656 \mathrm{~km}^{2}$ and SL decreased by $1413 \mathrm{~km}^{2}$ (Figure $5 \mathrm{~d}$ ). 


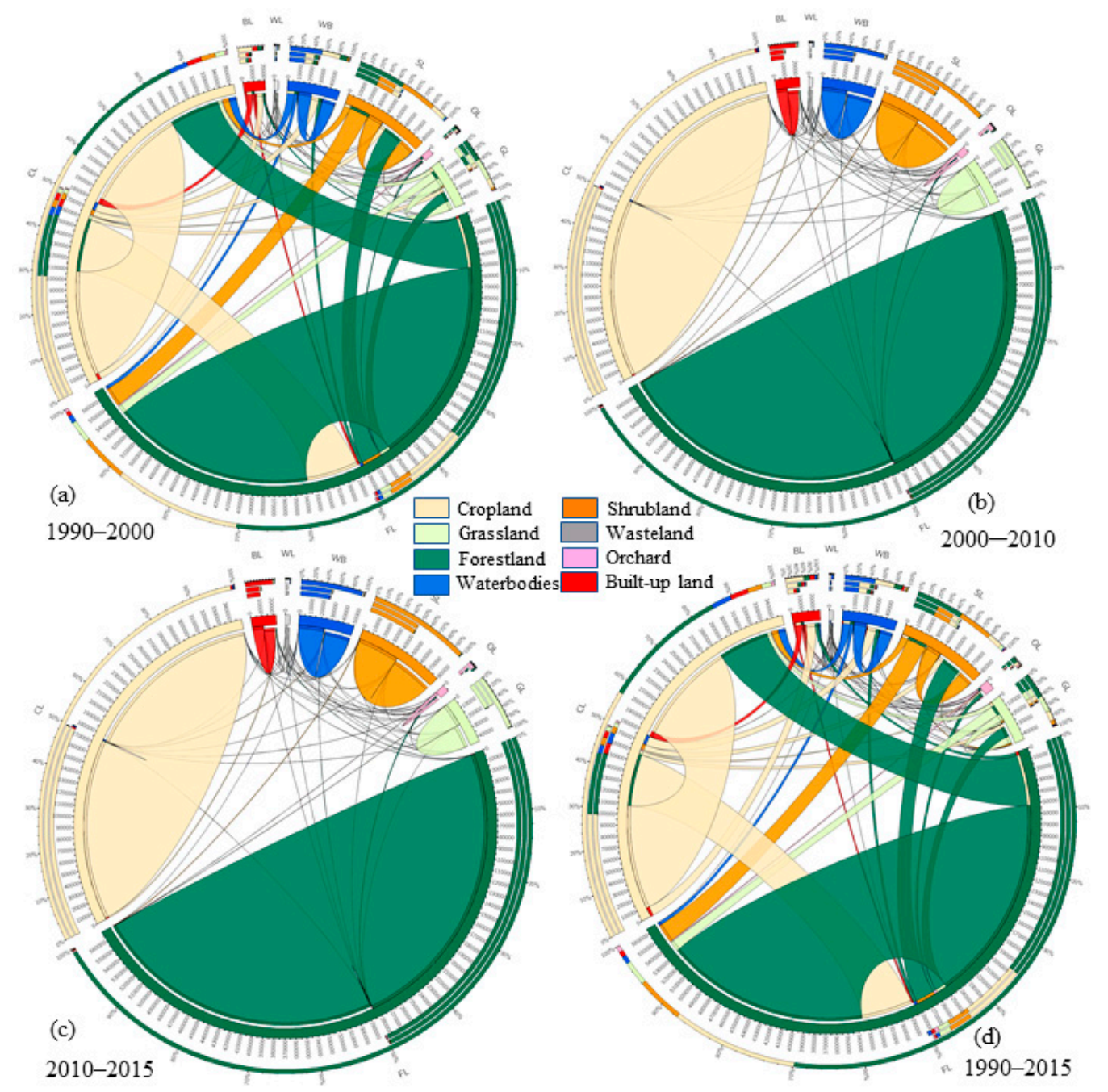

Figure 5. Land use transfer flow charts in the MRYRR from 1990 to 2015. (a) Land use transfer flow chart from 1990 to 2000. (b) Land use transfer flow chart from 2000 to 2010. (c) Land use transfer flow chart from 2010 to 2015. (d) Land use transfer flow chart from 1990 to 2015.

\subsection{Changes in Landscape Patterns in MRYRR from 1990 to 2015}

\subsubsection{Changes Metrics of Landscape Scale in the Study Area}

From 1990 to 2015, the PD of MRYRR increased and the landscape patterns became increasingly fragmented. The increase of SHDI indicated that the landscape pattern had became heterogeneous and fragmented. The LPI increased from 44.43 to 44.96 from 1990 to 2000 , and then decreased to 44.13 , indicating that the dominant patch became more and more obvious from 1990 to 2000, and then gradually fragmented. The MPS and CONTAG decreased, indicating that landscape patches became more fragmented. On the whole, with the development of urbanization, the landscape fragmentation in the MRYRR becomes more obvious, and the landscape heterogeneity is enhanced (Figure 6).

\subsubsection{Changes of Horizontal Pattern of Landscape Types in the Study Area}

The LSI of BUL became complex, but patches are more concentrated. The COHESION of orchard increased before 2010, but after 2010, COHESION decreased. The patches of $\mathrm{CL}$ and FL became fragmented, with reduced connectivity and complex landscape shapes. During the period 1990 to 2015, the NP of BUL increased from 6232 to 7936, and the MPS increased from $1.57 \mathrm{~km}^{2}$ to $2.00 \mathrm{~km}^{2}$, indicating that the BUL was more concentrated. At the same time, the NP and LSI of CL increased from 1990 to 2015, while the LPI and MPS decreased, which indicated that CL was gradually fragmented (Figure 7). 

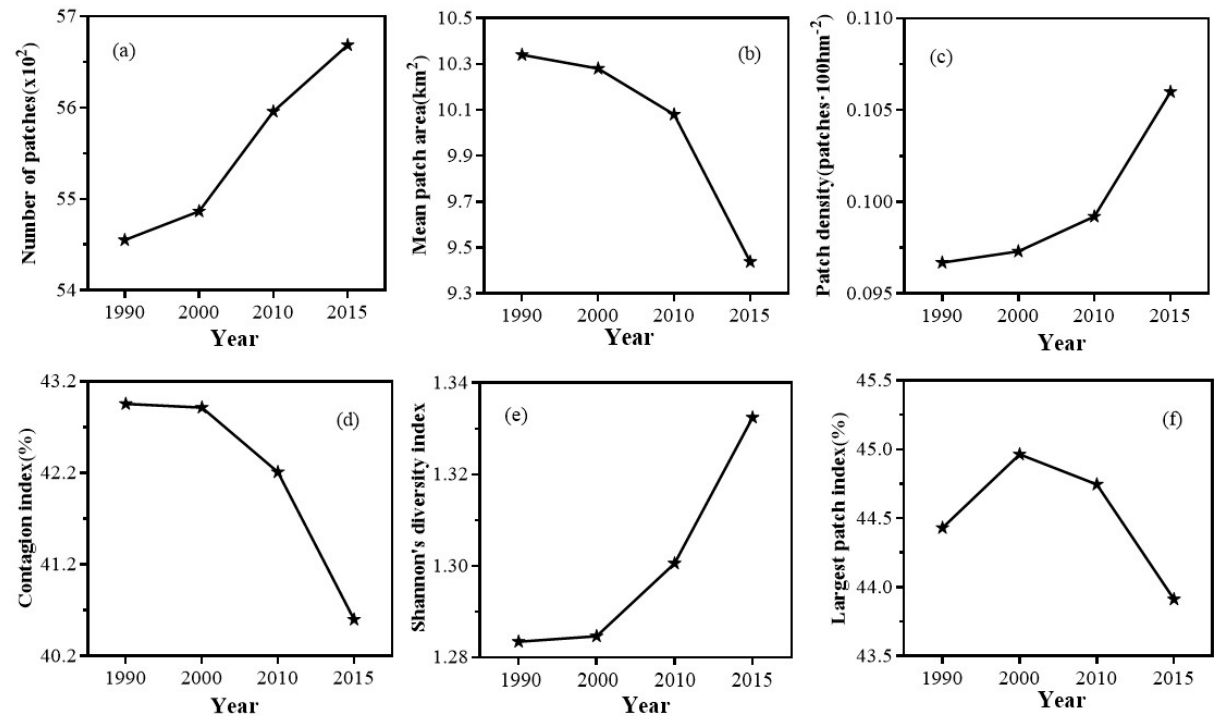

Figure 6. Landscape metrics in the MRYRR from 1990 to 2015. (a) Number of patches from 1990 to 2015. (b) Mean patch area from 1990 to 2015. (c) Patch density patches from 1990 to 2015. (d) Contagion index from 1990 to 2015. (e) Shannon's diversity index from 1990 to 2015. (f) Largest patch index from 1990 to 2015.
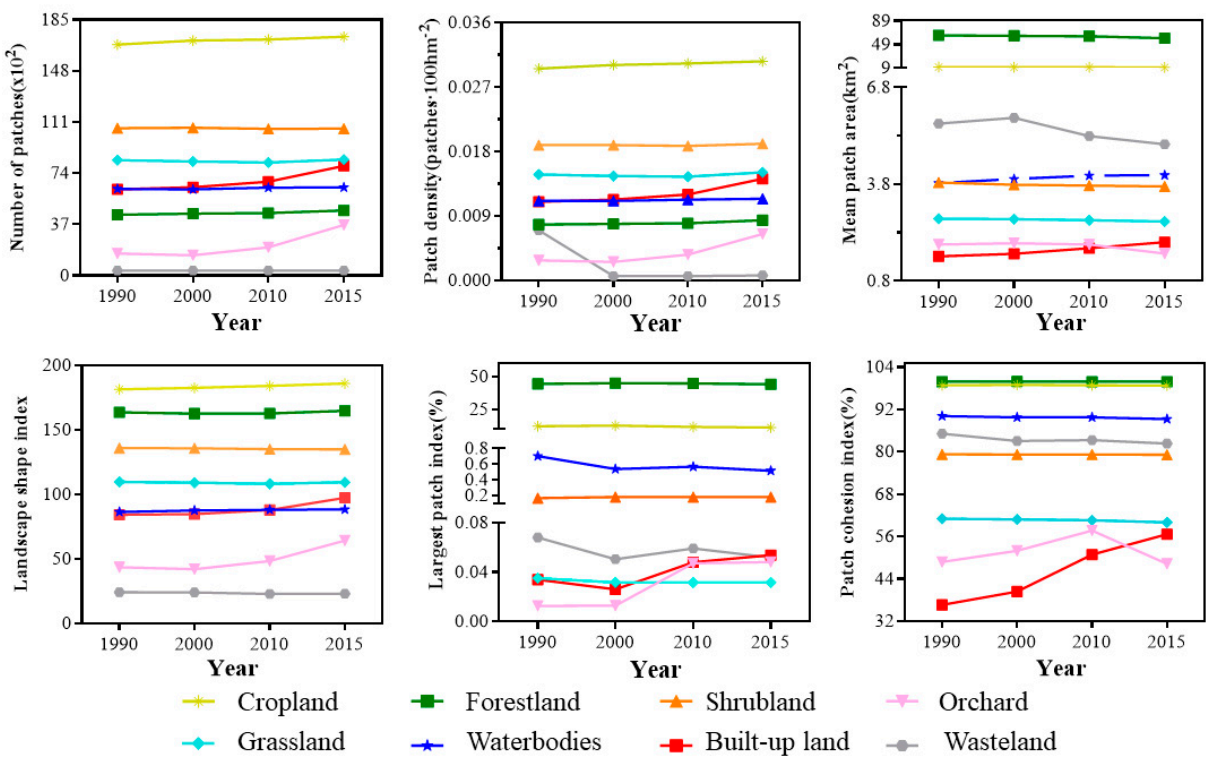

Figure 7. Landscape metrics on each type of land use in the MRYRR from 1990 to 2015.

The MPS of FL decreased from $64.45 \mathrm{~km}^{2}$ to $59.56 \mathrm{~km}^{2}$ during the period, and LSI decreased from 163.66 to 162.52 from 1990 to 2000, then increased to 164.71 in 2015. The COHESION was consistently at a high level (99.89\%). The NP and MPS of WL firstly increased and then decreased. The MPS of SL gradually decreased (Figure 7).

\subsection{Urbanization Process and Its Relationship with Land Use and Landscape Pattern}

4.3.1. The Urbanization Process in MRYRR from 1990 to 2015

From 1990 to 2015, MRYRR underwent rapid and noticeable urbanization. The GDP and PGDP increased by 36.03 times and 30.45 times, respectively. The PRI, SEC and TER increased by 8.28 times, 25.72 times and 39.5 times, respectively. During the time, POP increased from 32.35 million to 92.09 million. The RUR was gradually flowed into the cities, making the increase of URR an important factor of urbanization development. Over the past 25 years, the urbanization level in the study area increased from $21.19 \%$ to $51.43 \%$, an 
increase of 2.43 times. The increase of BL in this study also indicated the rapid urbanization in the MRYRR (Figure 8).
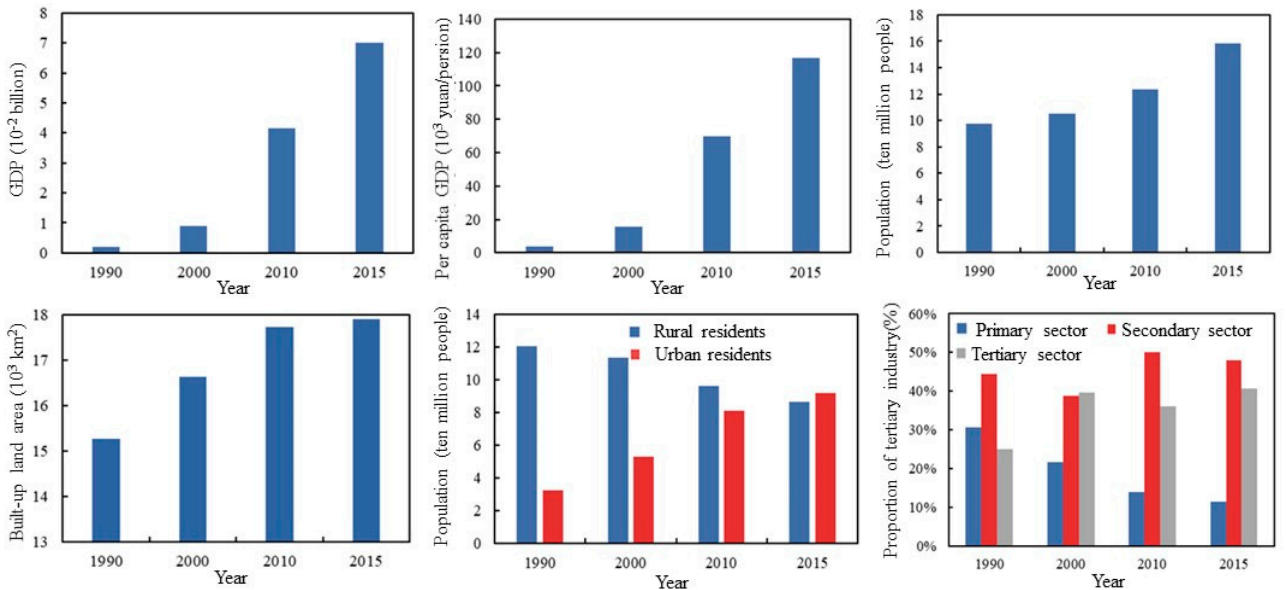

Figure 8. Socio-economic indicators in the middle reaches of the Yangtze River region from 1990 to 2015 .

\subsubsection{The Relationship between Land Use Change, Urbanization and Landscape} Driving Factors

The BL was negatively correlated with RUR and positively correlated with other factors. The correlation order was the TER $>$ GDP $>$ PGDP $>$ SEC $>$ PRI $>$ RUR $(p<0.05)$. The area of CL was positively correlated with RUR $(p<0.05)$, and negatively correlated with other factors, except POP, and the correlation order was the PGDP > GDP > PRI $>$ RUR $>$ TER $>$ SEC $>$ URR $(p<0.05)$. SL was negatively correlated with POP and RUR $(p<0.01)$, while SL was positively correlated with RUR $(p<0.05)(p<0.05)$ (Figure 9).

\begin{tabular}{|c|c|c|c|c|c|c|c|c|}
\hline & POP & RUR & URR & GDP & PGDP & PRI & SEC & TER \\
\hline $\mathrm{CL}$ & -0.923 & $0.987^{*}$ & $-0.974 *$ & $-0.988 *$ & $-0.989^{*}$ & $-0.988^{*}$ & $-0.983^{*}$ & $-0.987 *$ \\
\hline FL & -0.435 & 0.696 & -0.590 & -0.797 & -0.793 & -0.735 & -0.800 & -0.837 \\
\hline SL & $-0.992 * *$ & $0.972 *$ & $-0.996 * *$ & -0.933 & -0.935 & -0.958 & -0.925 & -0.914 \\
\hline $\mathrm{OL}$ & 0.727 & -0.905 & 0.839 & $0.959^{*}$ & $0.957^{*}$ & 0.927 & $0.958^{*}$ & $0.977 *$ \\
\hline GL & $-0.960 *$ & 0.857 & -0.916 & -0.769 & -0.773 & -0.827 & -0.766 & -0.720 \\
\hline WB & $0.986^{*}$ & $-0.980 *$ & $0.997 * *$ & 0.938 & 0.940 & $0.966^{*}$ & 0.934 & 0.911 \\
\hline BL & 0.829 & $-0.953^{*}$ & 0.912 & $0.984 *$ & $0.983 *$ & $0.965^{*}$ & $0.980^{*}$ & $0.996 * *$ \\
\hline WL & -0.868 & $0.983^{*}$ & -0.945 & $-0.989^{*}$ & $-0.989^{*}$ & $-0.990 * *$ & $-0.993 * *$ & $-0.976^{*}$ \\
\hline NP & $0.892 *$ & -0.872 & 0.935 & 0.804 & 0.807 & 0.843 & 0.789 & 0.781 \\
\hline MPS & -0.761 & 0.911 & -0.858 & $-0.959^{*}$ & $-0.958^{*}$ & -0.929 & $-0.955^{*}$ & $-0.980 *$ \\
\hline PD & 0.737 & -0.894 & 0.837 & 0.947 & 0.945 & 0.913 & 0.942 & $0.971^{*}$ \\
\hline CONTAG & -0.757 & 0.918 & -0.860 & $-0.966 *$ & $-0.965^{*}$ & -0.937 & $-0.964 *$ & $-0.984 *$ \\
\hline SHDI & 0.789 & -0.943 & 0.889 & $0.983^{*}$ & $0.982 *$ & $0.960^{*}$ & $0.983 *$ & $0.993 * *$ \\
\hline LPI & -0.128 & 0.453 & -0.313 & -0.578 & -0.573 & -0.505 & -0.591 & 0.619 \\
\hline
\end{tabular}

Figure 9. Correlation of land use, landscape patterns and other factors in the MRYRR from 1999 to 2015. Green represents negative relationships and red represents positive relationships. The lighter the color, the weaker the correlation. The data in the frame represents the correlation coefficients between land use types. ${ }^{*}$ Means that $p$ less than $0.05 ;{ }^{* *}$ means that $p$ less than 0.01 . Details of the abbreviations are shown in Table A1. 
BL and OL were significantly positively correlated with economic factors (GDP, PGDP, SEC and TER), while CL, SL and WL were significantly negatively correlated with economic factors. From the perspective of landscape patterns, NP was positively correlated with POP. PD was positively correlated with TER. MPS and CONTAG were negatively correlated with GDP, PGDP, SEC and TER, and SHDI was positively correlated with GDP, PGDP, PRI, SEC and TER (Figure 9).

\section{Discussion}

Social and economic development, urbanization level and geographical conditions were important factors affecting the changes of regional land use types and landscape patterns [72,73]. This study revealed the spatial-temporal patterns and driving factors of land use change in MRYRR over the past 25 years. According to the research results, BL and OL increased by $1.08 \%$ and $0.54 \%$, respectively, from 1990 to 2015 , CL and FL decreased by $1.06 \%$ and $0.49 \%$ respectively (Figure 4 and Table 2). Compared with China's coastal urban agglomerations, MRYRR has less land use change. For example, BL in the Yangtze River Delta increased by $8.68 \%$ and CL decreased by $8.34 \%$ in the past 10 years. Over the last 16 years, BL in the pearl river delta increased by $9.98 \%, C L$ and FL decreased by $7.12 \%$ and $2.26 \%$, respectively $[74,75]$. The changes of land use types and landscape patterns in the MRYRR were consistent with its socio-economic level, geographical conditions and national development policies.

At the socioeconomic level, urbanization was an important driving force of landscape pattern change. The Yangtze River Delta and the Pearl River Delta were located in the coastal areas, opening up to the outside world earlier and developing rapidly. The demand for BL was strong, leading to the acceleration of CL reduction [76-78]. Statistics showed that the development intensity of Shanghai and Beijing were $36.5 \%$ and $48 \%$; however, the development intensity in London and Tokyo was only $23.75 \%$ and $29.4 \%$ [79]. MRYRR, located in central and western China, has relatively slow economic development and urban population growth, and has a weak impact on CL and FL. Since 2016, the development of the Yangtze River economic belt had been implemented as a national strategy, and the economic development would increase rapidly. Therefore, the land use change in the study area should learn from the development experience and lessons of other regions in order to adapt to the sustainable development of social economy and environment.

At the level of natural environment, geographical environment has a restriction effect on land use changes. The Yangtze River Delta and the Pearl River Delta were mainly deltas and alluvial plains formed by the estuaries. The lack of natural barriers in mountainous regions limits land development and promotes land use disorder. Hilly areas in the three provinces of the MRYRR made up more than half of the total area [80,81]. Even in the middle delta of Wuhan, Changsha and Nanchang, the capital cities of the study area, there were still a large number of mountainous areas, which restrict the expansion of urbanization to a certain extent. However, with the development of urbanization in the past 25 years, the landscape fragmentation in this area became more and more serious, and the complexity of patch shape increased, even in the marginal areas, which had a negative impact on the maintenance of its ecosystem function.

At the level of national development strategies, land use was also affected by policies. The MRYRR area has implemented the Yangtze River Shelterbelt and the project of Grain to Green. In recent years, the implementation of ecological engineering and the promulgation of protection policies provided favorable conditions for the landscape ecological protection in this region, and also affected the landscape patterns $[82,83]$. SL has been the dominant land type in the study area for the past 25 years, and the area still maintains a high proportion of natural ecosystems, which provides a basis for development based on ecological conservation. However, due to the high intensity of human activities, the $\mathrm{CL}$ and $\mathrm{FL}$ in the region decreased, and the degree of landscape fragmentation was still increasing. Therefore, the protection of basic farmland and the control of urban expansion 
scale should be done well, and the maintenance of natural ecosystem connectivity should be strengthened.

\section{Conclusions}

From 1990 to 2015, with the rapid development of urbanization, BL increased by more than half in MRYRR, mainly by occupying CL and FL. BL gradually aggregated into the main patch of the core urban area. At the same time, the CL and FL were fragmented. During this period, the overall landscape of MRYRR became more heterogeneous and fragmented. The increase of economic and demographic factors in the study area was positively correlated with $\mathrm{BL}, \mathrm{OL}$ and SHID, and negatively correlated with $\mathrm{CL}, \mathrm{WL}$, MPS and CONTAG. Urbanization had a profound impact on the local land use and landscape patterns.

As the central region of the Yangtze River Economic Belt, the MRYRR is facing rapid economic development and the continuous improvement in urbanization, which may cause a strong negative impact on the existing ecological landscape patterns. This is already happening in the Yangtze River Delta and Pearl River Delta regions. The following measures should be adopted for a sustainable development: (1) The government should strictly implement the ecological protection strategies, delimiting ecological idle space and form strict systems; (2) The MRYRR has many mountains and hills. Urban roads and dams will lead to habitat fragmentation and ecological corridor fragmentation. Therefore, the connectivity of ecological patches should be increased to improve ecological nodes and corridors; (3) The MRYRR is the site of the Three Gorges Dam and needs strong water conservation forests to improve forest ecosystem services. This study has important reference value for ecological development and rational planning of land development, and utilization in the Yangtze River Basin and other similar regions.

Author Contributions: Conceptualization, Y.Y. and M.S.; methodology, H.K.; software, Y.Y.; validation, G.Z.; formal analysis, L.X.; investigation, Q.Z.; resources, C.Z., H.S. and J.L.; data curation, Y.L., X.Z., H.K. and N.Y.; writing-original draft preparation, Y.Y.; writing-review and editing, Y.Y., H.K.; visualization, Y.Y.; supervision, M.S.; project administration, C.Z.; funding acquisition, H.K. All authors have read and agreed to the published version of the manuscript.

Funding: This research was supported by National Natural Science Foundation of China (31770746), Youth initiation project of Shanghai Academy of landscape planning (KT00262), National Key R\&D Program of China (2017YFC0505501), the National Natural Science Foundation of China (31800411), and Special Project of Shanghai Municipal Economy and Information Technology Commission (201901024).

Institutional Review Board Statement: Not applicable.

Informed Consent Statement: Not applicable.

Conflicts of Interest: The authors declare that they have no known competing financial interest or personal relationships that could have appeared to influence the work reported in this paper.

\section{Appendix A}

Table A1. Land use types, landscape metrics and other factors abbreviations.

\begin{tabular}{ccc}
\hline Types & Abbreviation & Content \\
\hline & GL & Grassland \\
CL & Cropland \\
Land use types & SL & Shrubland \\
& OL & Orchard \\
& BL & Built-up land \\
& WL & Wasteland \\
& WB & Water bodies \\
& FL & Forestland \\
\hline
\end{tabular}


Table A1. Cont.

\begin{tabular}{ccc}
\hline Types & Abbreviation & Content \\
\hline & NP & Number patches \\
PD & Patch density \\
LPI & Largest Patch Index \\
& MPS & Mean Patch Area \\
& CONTAG & Contagion index \\
& SHID & Shannon diversity index \\
& COHESION & Patch Cohesion Index \\
& LSI & Landscape shape index \\
\hline & POP & Population \\
& RUR & Rural residents \\
URR & Urban residents \\
& GDP & Gross domestic product \\
& PGDP & Per capital Gross domestic product \\
& PRI & Primary sector \\
& SEC & Secondary sector \\
& TER & Tertiary sector \\
\hline Others & MRYRR & Middle reaches of the Yangtze River region \\
\hline
\end{tabular}

Table A2. Changes in area of land use types in the MRYRR region from 1990 to 2015.

\begin{tabular}{|c|c|c|c|c|c|c|c|c|}
\hline \multirow[b]{2}{*}{$\begin{array}{l}\text { Land Use } \\
\text { Types }\end{array}$} & \multicolumn{2}{|c|}{1990} & \multicolumn{2}{|c|}{2000} & \multicolumn{2}{|c|}{2010} & \multicolumn{2}{|c|}{2015} \\
\hline & $\begin{array}{c}\text { Area } \\
\left(\mathbf{k m}^{2}\right)\end{array}$ & $\begin{array}{c}\text { Percentage } \\
(\%)\end{array}$ & $\begin{array}{c}\text { Area } \\
\left(\mathrm{km}^{2}\right)\end{array}$ & $\begin{array}{c}\text { Percentage } \\
(\%)\end{array}$ & $\begin{array}{c}\text { Area } \\
\left(\mathbf{k m}^{2}\right)\end{array}$ & $\begin{array}{c}\text { Percentage } \\
(\%)\end{array}$ & $\begin{array}{c}\text { Area } \\
\left(\mathrm{km}^{2}\right)\end{array}$ & $\begin{array}{c}\text { Percentage } \\
(\%)\end{array}$ \\
\hline CL & 177,513 & 31.47 & 175,989 & 31.2 & 173,947 & 30.84 & 171,497 & 30.41 \\
\hline FL & 283,779 & 50.31 & 284,958 & 50.52 & 284,246 & 50.4 & 280,971 & 49.82 \\
\hline SL & 41,060 & 7.28 & 40,458 & 7.17 & 39,899 & 7.07 & 39,647 & 7.03 \\
\hline OL & 3072 & 0.54 & 2909 & 0.52 & 3957 & 0.7 & 6077 & 1.08 \\
\hline GL & 22,786 & 4.04 & 22,403 & 3.97 & 21,931 & 3.89 & 22,130 & 3.92 \\
\hline WB & 23,945 & 4.25 & 24,687 & 4.38 & 25,784 & 4.58 & 26,003 & 4.61 \\
\hline BL & 9762 & 1.73 & 10,511 & 1.86 & 12,336 & 2.19 & 15,865 & 2.81 \\
\hline$\overline{W L}$ & 2083 & 0.37 & 2085 & 0.37 & 1900 & 0.34 & 1810 & 0.32 \\
\hline
\end{tabular}

Table A3. Land use transfer matrix in the middle reaches of the Yangtze River from 1990 to $2000\left(\mathrm{~km}^{2}\right)$.

\begin{tabular}{cccccccccc}
\hline & CL & FL & SL & OL & GL & WB & BL & WL & 1990 \\
\hline CL & $102,176.00$ & $51,661.00$ & 5242.00 & 772.00 & 3736.00 & 7555.00 & 6080.00 & 291.00 & $177,513.00$ \\
\hline FL & $49,664.00$ & $199,864.00$ & $18,792.00$ & 1146.00 & 9799.00 & 2891.00 & 1583.00 & 40.00 & $283,779.00$ \\
\hline SL & 6363.00 & $19,093.00$ & $14,581.00$ & 125.00 & 223.00 & 472.00 & 196.00 & 7.00 & $41,060.00$ \\
\hline OL & 797.00 & 1215.00 & 144.00 & 590.00 & 0.00 & 0.00 & 326.00 & 0.00 & 3072.00 \\
\hline GL & 3980.00 & 8010.00 & 1026.00 & 103.00 & 8632.00 & 0.00 & 390.00 & 645.00 & $22,786.00$ \\
\hline WB & 7180.00 & 3138.00 & 673.00 & 173.00 & 0.00 & $12,781.00$ & 0.00 & 0.00 & $23,945.00$ \\
\hline BL & 5579.00 & 1929.00 & 0.00 & 0.00 & 0.00 & 306.00 & 1916.00 & 32.00 & 9762.00 \\
\hline WL & 250.00 & 48.00 & 0.00 & 0.00 & 13.00 & 682.00 & 20.00 & 1070.00 & 2083.00 \\
\hline 2000 & $175,989.00$ & $284,958.00$ & $40,458.00$ & 2909.00 & $22,403.00$ & $24,687.00$ & $10,511.00$ & 2085.00 & $64,500.00$ \\
\hline
\end{tabular}

NOTE: The data in each row added up to the total area of land use in the same category in 1990, and the data in each column equalled the total area of land use in the same category in 2000. The data in each cell represented the area of the row land use type transferred to column land use type from 1990 to 2000 . The total area of the study area is $64,500 \mathrm{~km}^{2}$. 
Table A4. Land use transfer matrix in the middle reaches of the Yangtze River from 2000 to $2010\left(\mathrm{~km}^{2}\right)$.

\begin{tabular}{cccccccccc}
\hline & CL & FL & SL & OL & GL & WB & BL & WL & 2000 \\
\hline CL & $173,418.00$ & 162.00 & 22.00 & 157.00 & 15.00 & 969.00 & 1221.00 & 25.00 & $177,513.00$ \\
\hline FL & 194.00 & $283,100.00$ & 40.00 & 966.00 & 34.00 & 149.00 & 474.00 & 1.00 & $283,779.00$ \\
\hline SL & 20.00 & 504.00 & $39,803.00$ & 54.00 & 3.00 & 30.00 & 41.00 & 3.00 & $41,060.00$ \\
\hline OL & 6.00 & 127.00 & 8.00 & 2738.00 & 5.00 & 9.00 & 16.00 & 0.00 & 3072.00 \\
\hline GL & 59.00 & 331.00 & 26.00 & 37.00 & $21,846.00$ & 69.00 & 30.00 & 5.00 & $22,786.00$ \\
\hline WB & 227.00 & 19.00 & 0.00 & 3.00 & 25.00 & $24,172.00$ & 82.00 & 159.00 & $23,945.00$ \\
\hline BL & 7.00 & 3.00 & 0.00 & 2.00 & 0.00 & 23.00 & $10,471.00$ & 5.00 & 9762.00 \\
\hline WL & 16.00 & 0.00 & 0.00 & 0.00 & 3.00 & 363.00 & 1.00 & 1702.00 & 2083.00 \\
\hline $\mathbf{2 0 1 0}$ & $173,947.00$ & $284,246.00$ & $39,899.00$ & 3957.00 & $21,931.00$ & $25,784.00$ & $12,336.00$ & 1900.00 & $64,500.00$ \\
\hline
\end{tabular}

Note: The data in each row added up to the total area of land use in the same category in 2000, and the data in each column equalled the total area of land use in the same category in 2010. The data in each cell represented the area of the row land use type transferred to column land use type from 2000 to 2010 . The total area of the study area is $64,500 \mathrm{~km}^{2}$.

Table A5. Land use transfer matrix in the middle reaches of the Yangtze River from 2010 to $2015\left(\mathrm{~km}^{2}\right)$.

\begin{tabular}{cccccccccc}
\hline & CL & FL & SL & OL & GL & WB & BL & WL & 2010 \\
\hline CL & $171,180.00$ & 65.00 & 3.00 & 240.00 & 15.00 & 316.00 & 2123.00 & 5.00 & $173,947.00$ \\
\hline FL & 96.00 & $280,644.00$ & 38.00 & 1871.00 & 394.00 & 76.00 & 1127.00 & 0.00 & $284,246.00$ \\
\hline SL & 5.00 & 37.00 & $39,588.00$ & 112.00 & 20.00 & 16.00 & 121.00 & 0.00 & $39,899.00$ \\
\hline OL & 18.00 & 132.00 & 8.00 & 3757.00 & 6.00 & 10.00 & 26.00 & 0.00 & 3957.00 \\
\hline GL & 11.00 & 33.00 & 2.00 & 88.00 & $21,683.00$ & 8.00 & 105.00 & 1.00 & $21,931.00$ \\
\hline WB & 127.00 & 24.00 & 6.00 & 3.00 & 11.00 & $25,450.00$ & 145.00 & 18.00 & $25,784.00$ \\
\hline BL & 59.00 & 36.00 & 2.00 & 5.00 & 0.00 & 16.00 & $12,218.00$ & 0.00 & $12,336.00$ \\
\hline WL & 1.00 & 0.00 & 0.00 & 1.00 & 1.00 & 111.00 & 0.00 & 1786.00 & 1900.00 \\
\hline $\mathbf{2 0 1 5}$ & $171,497.00$ & $280,971.00$ & $39,647.00$ & 6077.00 & $22,130.00$ & $26,003.00$ & $15,865.00$ & 1810.00 & $64,500.00$ \\
\hline
\end{tabular}

Note: The data in each row added up to the total area of land use in the same category in 2010, and the data in each column equalled the total area of land use in the same category in 2015. The data in each cell represented the area of the row land use type transferred to column land use type from 2010 to 2015 . The total area of the study area is $64,500 \mathrm{~km}^{2}$.

Table A6. Land use transfer matrix in the middle reaches of the Yangtze River from 1990 to 2015.

\begin{tabular}{cccccccccc}
\hline & CL & FL & SL & OL & GL & WB & BL & WL & 1990 \\
\hline CL & $99,138.00$ & $50,062.00$ & 5152.00 & 1502.00 & 3658.00 & 8751.00 & 8950.00 & 300.00 & $177,513.00$ \\
\hline FL & $48,910.00$ & $197,041.00$ & $18,427.00$ & 3260.00 & 9887.00 & 3075.00 & 3134.00 & 45.00 & $283,779.00$ \\
\hline SL & 6284.00 & $18,577.00$ & $13,675.00$ & 270.00 & 1404.00 & 483.00 & 361.00 & 6.00 & $41,060.00$ \\
\hline OL & 780.00 & 1199.00 & 136.00 & 658.00 & 160.00 & 74.00 & 62.00 & 3.00 & 3072.00 \\
\hline GL & 3943.00 & 9626.00 & 1802.00 & 251.00 & 6498.00 & 365.00 & 284.00 & 17.00 & $22,786.00$ \\
\hline WB & 6868.00 & 3014.00 & 303.00 & 89.00 & 390.00 & $11,689.00$ & 1047.00 & 545.00 & $23,945.00$ \\
\hline BL & 5327.00 & 1406.00 & 146.00 & 44.00 & 120.00 & 691.00 & 1991.00 & 37.00 & 9762.00 \\
\hline WL & 247.00 & 46.00 & 6.00 & 3.00 & 13.00 & 875.00 & 36.00 & 857.00 & 2083.00 \\
\hline $\mathbf{2 0 1 5}$ & $171,497.00$ & $280,971.00$ & $39,647.00$ & 6077.00 & $22,130.00$ & $26,003.00$ & $15,865.00$ & 1810.00 & $64,500.00$ \\
\hline
\end{tabular}

Note: The data in each row added up to the total area of land use in the same category in 1990, and the data in each column equalled the total area of land use in the same category in 2015. The data in each cell represented the area of the row land use type transferred to column land use type from 1990 to 2015 . The total area of the study area is $64,500 \mathrm{~km}^{2}$. 


\section{References}

1. Kalnay, E.; Cai, M. Impact of urbanization and land-use change on climate. Nature 2003, 423, 528-531. [CrossRef]

2. Kabir, A.; Sekine, M.; Imai, T.; Yamamoto, K. Assessing Small-Scale Freshwater Microplastics Pollution, Land-use, Source-to-Sink Conduits, and Pollution Risks: Perspectives from Japanese Rivers Polluted with Microplastics. Sci. Total Environ. 2021, 768, 144655. [CrossRef]

3. Shen, J.; Qin, G.; Yu, R.; Zhao, Y. Urbanization has changed the distribution pattern of zooplankton species diversity and the structure of functional groups. Ecological. Indic. 2021, 120, 106944. [CrossRef]

4. Tian, L.; Guo, Y. Peri-Urban China: Land Use, Growth, and Integrated Urban-Rural Development; Routledge: London, UK, 2019.

5. Liu, D.; Zheng, X.; Wang, H. Land-use Simulation and Decision-Support system (LandSDS): Seamlessly integrating system dynamics, agent-based model, and cellular automata. Ecol. Model. 2020, 417, 108924. [CrossRef]

6. Yi, Y.; Zhao, Y.; Ding, G.; Gao, G.; Shi, M.; Cao, Y. Effects of Urbanization on Landscape Patterns in a Mountainous Area: A Case Study in the Mentougou District, Beijing, China. Sustainability 2016, 8, 1190. [CrossRef]

7. Zhu, Z.; He, Q.Y. Spatio-temporal Evaluation of the Urban Agglomeration Expansion in the Middle Reaches of the Yangtze River and Its Impact on Ecological Lands. Sci. Total Environ. 2021, 790, 148150.

8. Dadashpoor, H.; Azizi, P.; Moghadasi, M. Land use change, urbanization, and change in landscape pattern in a metropolitan area. Sci. Total Environ. 2019, 655, 707-719. [CrossRef]

9. National Bureau of Statistics of the People's Republic of China. China Statistical Yearbook 2010; China Statistics Press: Beijing, China, 2011.

10. National Bureau of Statistics of the People's Republic of China. China Statistical Yearbook 2019; China Statistics Press: Beijing, China, 2020.

11. Yang, Y. Spatiotemporal change characteristics of land landscape pattern in mountainous areas since reform and opening up: A case study of Mentougou District, Beijing. Subtrop. Soil Water Conserv. 2021, 33, 12-18. (In Chinese)

12. Li, C.G.; Yin, H.F.; Chen, D.X.; Wang, B. Flood control problems and countermeasures in the middle reaches of the Yangtze River-Enlightenment from the devastating flood in 1998. Earth Sci. 1999, 4, 329-334. (In Chinese)

13. Yi, Y.; Shi, M.; Liu, C.; Kang, H.; Wang, B. On landscape patterns in typical mountainous counties of middle reaches of the Yangtze River in China. Int. J. Environ. Res. Public Health 2021, 18, 4000. [CrossRef]

14. Zheng, W.W. A preliminary study on reasonable forest species structure and forest coverage rate in the Three Gorges Reservoir Area [D]. Beijing For. Univ. 2006, 6, 610-613. (In Chinese)

15. Arki, V.; Koskikala, J.; Fagerholm, N.; Kisanga, D.; K Käyhköa, N. Associations between local land use/land cover and place-based landscape service patterns in rural Tanzania. Ecosyst. Serv. 2020, 41, 101056. [CrossRef]

16. Shehab, Z.N.; Jamil, N.R.; Aris, A.Z.; Shafie, N.S. Spatial variation impact of landscape patterns and land use on water quality across an urbanized watershed in Bentong. Malaysia. Ecol. Indic. 2021, 122, 107254. [CrossRef]

17. Turner, B.L.; Skole, D.; Sanderson, S.; Fischer, G.; Fresco, L.; Leemans, R. Land Use and Land Cover Change: Science/Research Plan; IGBP Report No.35 and HDP Report No.7; IGBP: Stockholm, Sweden, 1995; pp. 2-15.

18. Castella, J.C.; Kam, S.P.; Dang, D.Q.; Verburg, P.H.; Ch, T.H. Combining top-down and bottom-up modelling approaches of land use/cover change to support public policies: Application to sustainable management of natural resources in northern Vietnam. Land Use Policy 2007, 24, 531-545. [CrossRef]

19. Verburg, P.H.; Schot, P.P.; Dijst, M.J.; Veldkamp, A. Land use change modelling: Current practice and research priorities. Geojournal 2004, 61, 309-324. [CrossRef]

20. Spencer, R.; Meyer, K.B.; Christopher, S.C.; Robert, J.L. An analysis of spatio-temporal landscape patterns for protected areas in northern New England: 1900-2010. Landsc. Ecol. 2015, 30, 1291-1305.

21. Zhou, Y.Y.; Yue, D.X.; Guo, J.J.; Chen, G.G.; Wang, D. Spatial correlations between landscape patterns and net primary productivity: A case study of the Shule River Basin, China. Ecol. Indic. 2021, 130, 94-104. [CrossRef]

22. Forman, R.T.T.; Godron, M. Landscape Ecology; John Wiley \& Sons: New York, NY, USA, 1986.

23. Pickett, S.T.A.; Cadenasso, M.L. Landscape ecology: Spatial heterogeneity in ecological systems. Science 1995, 269, 331-334. [CrossRef]

24. Turner, M.G.; Gardner, R.H. Quantitative Methods in Landscape Ecology; Springer: New York, NY, USA, 1991.

25. Risser, P.G.; Iverson, L.R. 30 years later-landscape ecology: Directions and approaches. Landsc. Ecol. 2013, 28, 367-369. [CrossRef]

26. Wang, X.L.; Xiao, D.N. Landscape pattern analysis of liaohe Delta wetland. Acta Ecol. Sin. 1997, 17, 317-323. (In Chinese)

27. Wu, J.; Levin, S.A. A spatial patch dynamic modeling approach to pattern and process in an annual grassland. Ecol. Monogr. 1994, 64, 447-464. [CrossRef]

28. Mas, J.F.; Velázquez, A.; Díaz-Gallegos, J.R.; Mayorga-Saucedo, R.; Alcántara, C.; Bocco, G.; Castro, R.; Fernández, T.; Pérez-Vega, A. Assessing land use/cover changes: A nationwide multidate spatial database for Mexico. Int. J. Appl. Earth Obs. Geoinf. 2004, 5, 249-261. [CrossRef]

29. Ruddiman, W.F.; Ellis, E.C. Effect of per-capita land use changes on Holocene forest clearance and $\mathrm{CO}_{2}$ emissions. Quat. Sci. Rev. 2009, 28, 3000-3015. [CrossRef]

30. York, A.M.; Munroe, D.K. Urban encroachment, forest regrowth and land-use institutions: Does zoning matter? Land Use Policy 2010, 27, 471-479. [CrossRef]

31. Fu, B.; Wang, Y.F.; Lu, Y.H.; He, C.S.; Chen, L.; Song, C.J. The effects of land use combination on soil erosion-a case study in Loess Plateau of China. Prog. Phys. Geogr. 2009, 33, 793-804. [CrossRef] 
32. Jansen, L.J.M.; Gregorio, A.D. Land-use data collection using the "land cover classification system": Results from a case study in Kenya. Land Use Policy 2003, 20, 131-148. [CrossRef]

33. Antrop, M. Landscape change and the urbanization process in Europe. Landsc. Urban Plan. 2004, 67, 9-26. [CrossRef]

34. Wu, J.G.; Jenerette, G.D.; Buyantuyev, A.; Redman, C.L. Quantifying spatiotemporal patterns of urbanization: The case of the two fastest growing metropolitan regions in the United States. Ecol. Complex. 2011, 8, 1-8. [CrossRef]

35. Zhu, C.M.; Zhang, X.L.; Zhou, M.M.; He, S.; Gan, M.Y.; Yang, L.X.; Wang, K. Impacts of urbanization and landscape pattern on habitat quality using OLS and GWR models in Hangzhou, China. Ecol. Indic. 2020, 117, 106654. [CrossRef]

36. Zhu, Z.; Zhu, X. Study on Spatiotemporal Characteristic and Mechanism of Forest Loss in Urban Agglomeration in the Middle Reaches of the Yangtze River. Forests 2021, 12, 1242. [CrossRef]

37. Du, X.; Huang, Z. Ecological and environmental effects of land use change in rapid urbanization: The case of hangzhou, China. Ecol. Indicator. 2017, 81, 243-251. [CrossRef]

38. Chen, W.; Chi, G.; Li, J. The spatial association of ecosystem services with land use and land cover change at the county level in China 1995-2015. Sci. Total Environ. 2019, 669, 459-470. [CrossRef] [PubMed]

39. Yuan, Z.; Xu, J.; Wang, Y.; Yan, B. Analyzing the influence of land use/land cover change on landscape pattern and ecosystem services in the Poyang Lake Region, China. Environ. Sci. Pollut. Res. 2021, 28, 27193-27206. [CrossRef] [PubMed]

40. Mark, M.; Fu, B. Evaluation of landscape pattern and fragmentation in Dongling Mountain area, Beijing. Chin. J. Plant Ecol. 2000, 1, 320-326. (In Chinese)

41. Zhang, X.; Shi, P.J.; Luo, J.; Liu, H.; Wei, W. Ecological risk analysis of arid inland river basin based on Landscape Pattern: A case study of Shiyang River Basin. J. Nat. Resour. 2014, 29, 410-419.

42. Qi, Y.; Wu, J.G.; Li, J.L.; Yu, Y.; Peng, F.; Sun, C. Landscape pattern and driving forces of small and medium-sized cities in eastern and Western. China. Acta Ecol. Sin. 2013, 33, 275-285. (In Chinese)

43. Fan, Y.; Gan, L.; Hong, C.; Jessup, L.H.; Lu, L. Spatial identification and determinants of trade-offs among multiple land use functions in Jiangsu Province, China. Sci. Total Environ. 2021, 772, 145022. [CrossRef]

44. Kim, J.H.; Kwon, O.S.; Ra, J.H. Urban Type Classification and Characteristic Analysis through Time-Series Environmental Changes for Land Use Management for 31 Satellite Cities around Seoul, South Korea. Land 2021, 10, 799. [CrossRef]

45. Huang, C.; Huang, X.; Peng, C.; Zhou, Z.; Teng, M.; Wang, P. Land use/cover change in the Three Gorges Reservoir area, China: Reconciling the land use conflicts between development and protection. Catena 2019, 175, 388-399. [CrossRef]

46. Asimeh, M.; Nooripoor, M.; Azadi, H.; Hossein, A.; Veerle, V.E.; Petr, S.; Frank, W. Agricultural land use sustainability in Southwest Iran: Improving land leveling using consolidation plans. Land Use Policy 2020, 94, 104555. [CrossRef]

47. Li, H.; Peng, J.; Liu, Y.; Hu, Y. Urbanization impact on landscape patterns in Beijing City, China: A spatial heterogeneity perspective. Ecol. Ind. 2017, 82, 50-60. [CrossRef]

48. Yi, Y.; Wang, B.; Shi, M.; Meng, Z.; Zhang, C. Variation in Vegetation and Its Driving Force in the Middle Reaches of the Yangtze River in China. Water 2021, 13, 2036. [CrossRef]

49. Ng, C.N.; Xie, Y.J.; Yu, X.J. Measuring the spatio-temporal variation of habitat isolation due to rapid urbanization: A case study of the Shenzhen River cross-boundary catchment, China. Landsc. Urban Plan. 2011, 103, 44-54. [CrossRef]

50. Pan, Z.; He, J.; Liu, D.; Wang, J.; Guo, X. Ecosystem health assessment based on ecological integrity and ecosystem services demand in the Middle Reaches of the Yangtze River Economic Belt, China. Sci. Total Environ. 2021, 774, 144837. [CrossRef]

51. Hu, X.L.; Yi, Y.; Kang, H.Z.; Wang, B.; Shi, M.C.; Liu, C.J. Temporal and spatial variations of land use and the driving factors in the middle reaches of the Yangtze River in the past 25 years. Acta Ecol. Sin. 2019, 39, 1877-1886. (In Chinese)

52. National Development and Reform Commission. Notice on the issuance of the "Development Plan for Triangle of Central China". [2015-04-13]. Available online: https://www.ndrc.gov.cn/xxgk/zcfb/ghwb/201606/t20160603_962187.html?code=\&state=123 (accessed on 14 August 2021).

53. Chen, Y.; Zhang, S.; Huang, D.; Li, B.L.; Liu, J.; Liu, W. The development of China's Yangtze River Economic Belt: How to make it in a green way? Sci. Bull. 2017, 62, 648-651. [CrossRef]

54. Chen, D.S.; Jiang, P.H.; Li, M.C. Assessing potential ecosystem service dynamics driven by urbanization in the Yangtze River Economic Belt, China. J. Environ. Manag. 2021, 292, 112734. [CrossRef]

55. Ma, J.; Li, X.F.; Zhang, H. Study on the coordination of urban development quality system in the middle reaches of the Yangtze River. Econ. Geogr. 2016, 36, 53-61.

56. Huang, M.Y.; Yue, W.Z.; Xiang, H.E. Decoupling relationship between urban expansion and economic growth in the Yangtze River economic belt and its spatial heterogeneity. J. Nat. Resour. 2018, 33, 219-232.

57. Wu, H.; Hu, X.; Sun, S.; Dai, J.; Ye, S.J.; Du, C.Y.; Chen, H.; Yu, G.L.; Zhou, L.; Chen, J. Effect of increasing of water level during the middle of dry season on landscape pattern of the two largest freshwater lakes of China. Ecol. Indic. 2020, 113, 106283. [CrossRef]

58. Chen, W.; Zhao, H.; Li, J.; Zhu, L.; Wang, Z.; Zeng, J. Land use transitions and the associated impacts on ecosystem services in the middle reaches of the Yangtze River economic belt in China based on the geo-informatic Tupu method. Sci. Total Environ. 2020, 701, 134690. [CrossRef]

59. Long, H.L.; Heilig, G.K.; Wang, J.; Li, X.B.; Luo, M.; Wu, X.Q.; Zhang, M. Land use and soil erosion in the upper reaches of the Yangtze River: Some socio-economic considerations on China's Grain-for-Green Programme. Land Degrad. Dev. 2006, 17, 589-603. [CrossRef]

60. United States Geological Survey. Remote Sensing Images. Available online: https:/ /www.usgs.gov/ (accessed on 17 April 2018). 
61. Chinese Academy of Sciences. National Earth System Science Data Sharing Infrastructure. Available online: http://www.geodata. $\mathrm{cn} /$ (accessed on 17 April 2018).

62. Hubei Provincial Bureau of Statistics. Statistical Bulletin of National Economic and Social Development of Hubei Province in 2015. 2016. Available online: http:/ / tjj.hubei.gov.cn/tjsj/sjkscx/tjnj/qstjnj/ (accessed on 10 April 2021).

63. Hunan Provincial Bureau of Statistics. Statistical Bulletin of National Economic and Social Development of Hunan Province in 2015. 2016. Available online: www.hunan.gov.cn/zfsj/tjgb/201604/t20160422_4832916.html (accessed on 10 April 2021).

64. Jiangxi Provincial Bureau of Statistics. Statistical Bulletin of National Economic and Social Development of Jiangxi Province in 2015. 2016. Available online: Tjj.jiangxi.gov.cn/art/2016/11/24/art_38773_2343871.html (accessed on 10 April 2021).

65. China's national standard (GB/T 21010-2017). Current Land Use Condition Classification. Available online: http:/ / www.gov.cn/ xinwen/2017-11/04/content_5237211.htm (accessed on 1 November 2017).

66. Gonzalez-Avila, S.; Lopez-Leiva, C.; Bunce, R.G.H.; Elena-Rosselló, R. Changes and drivers in Spanish landscapes at the Rural-Urban Interface between 1956 and 2018. Sci. Total Environ. 2020, 714, 136858.1-136858.10. [CrossRef]

67. Liu, R.; Zhu, D. Discussion on land use change information mining method based on transition matrix. Resour. Sci. 2010, 32, 1544-1550.

68. Krzywinski, M.I.; Schein, J.E.; Birol, I.; Connors, J.; Gascoyne, R.; Horsman, D.; Jones, S.J.; Marra, M.A. Circos: An information aesthetic for comparative genomics. Genome Res. 2009, 19, 1639-1645. [CrossRef]

69. Su, S.; Xiao, R.; Zhang, Y. Multi-scale analysis of spatially varying relationships between agricultural landscape patterns and urbanization using geographically weighted regression. Appl. Geography. 2012, 32, 360-375. [CrossRef]

70. Xiao, R.; Wang, G.; Zhang, Q.; Zhang, Z. Multi-scale analysis of relationship between landscape pattern and urban river water quality in different seasons. Sci. Rep. 2016, 6, 25250. [CrossRef]

71. Hope, A.S.; Boynton, W.L.; Stow, D.A.; Douglas, D.C. Interannual growth dynamics of vegetation in the Kuparuk River watershed, Alaska based on the Normalized Difference Vegetation Index. Int. J. Remote Sens. 2003, 24, 3413-3425. [CrossRef]

72. Zhou, D.; Xu, J.C.; Wang, L.; Lin, Z.L. Assessing urbanization quality using structure and function analyses: A case study of the urban agglomeration around Hangzhou Bay (UAHB), China. Habitat Int. 2015, 49, 165-176. [CrossRef]

73. Ye, C.; Zhu, J.J.; Li, S.M.; Chen, M.X. Assessment and analysis of regional economic collaborative development within an urban agglomeration: Yangtze River Delta as a case study. Habitat Int. 2019, 83, 20-29. [CrossRef]

74. Xu, N. Study on the Spatial Pattern of Land Use in the Yangtze River Delta from 2000 to 2010; Xi'an University of Science and Technology: Xi'an, China, 2014.

75. Ye, C.S.; Wang, F. Study on land use and landscape pattern change in Pearl River Delta. Bull. Soil Water Conserv. 2012, 32, $238-243$.

76. He, Y.; Wang, J.J.; Yuan, Z.J.; Zheng, M.G.; Huang, B.; Liang, C. Land use change and its response to urbanization in the Pearl River Delta. Ecol. Environ. Sci. 2020, 29, 303-310.

77. Zhu, B.; Zhang, T.L. The impact of cross-region industrial structure optimization on economy, carbon emissions and energy consumption: A case of the Yangtze River Delta. Sci. Total Environ. 2021, 778, 146089. [CrossRef]

78. Yu, Z.; Li, X.F.; Wang, S.R.; Liu, L.Y.; Zeng, E.Y. The human and ecological risks of neonicotinoid insecticides in soils of an agricultural zone within the Pearl River Delta, South China. Environ. Pollut. 2021, 284, 117358. [CrossRef]

79. Zhao, Y.; Liu, Y.Z.; Long, K.S. Characteristics and influencing factors of urban land development intensity in Yangtze River Delta. Resour. Environ. Yangtze Basin 2012, 21, 1480-1485.

80. Du, W.C.; Jiang, H. Analysis on the connotation and essence of "the ecological environment protection plan for the Yangtze River economic belt". Environ. Prot. 2017, 45, 51-56.

81. Kong, L.Q.; Zhang, L.; Zheng, H.; Xu, W.H.; Xiao, Y.; Ouyang, Z.Y. Evolution and driving forces of ecosystem pattern in the Yangtze River Basin. Acta Ecol. Sin. 2018, 38, 741-749. (In Chinese)

82. Chen, W.; Li, J.; Zhu, L. Spatial heterogeneity and sensitivity analysis of ecosystem services value in the Middle Yangtze River region. J. Nat. Resour. 2019, 34, 325-337.

83. Chen, W.; Ye, X.; Li, J.; Fan, X.; Liu, Q.; Dong, W. Analyzing requisition-compensation balance of farmland policy in China through telecoupling: A case study in the middle reaches of Yangtze River Urban Agglomerations. Land Use Policy 2019, 83, 134-146. [CrossRef] 